\title{
Asian Reform \& the Egyptian Renaissance
}

\section{By: Abdel Moeti Abu-Zaid Editor-in-Chief Head of Foreign Information Sector}

Several Asian countries have recently engaged in extensive economic reforms, especially following the health impacts of the covid19 pandemic on the world economy in general.

In this sense, the current issue of "Asian Perspectives" comprises a dossier highlighting the aspects, objectives, and results of economic reforms in Asia, especially in Indonesia, which has begun the process of reforming and restructuring the economy to recover in the postcovid-19 phase, as well as economic reform in Malaysia, which aims to return its successful economic experience to the same level of success and brilliance it has witnessed in the past.

This dossier also includes a case study on Hong Kong's experience in economic reform, which has been subject to domestic political challenges along with external pressures in recent times, as well as Vietnam's development process, with special focus on manufacturing, which has helped it achieve high growth rates and operating levels and generated employment opportunities on a large scale.

India, one of the world's largest economies, is in a state of constant reform and development, which has its social and cultural peculiarities, as well as its reflections on the economic side. India has made great achievements in the field of advanced industries and digital technology.

Finally, the dossier includes a case study of Singapore's experi- 
ence, which, despite its impressive economic progress, does not stop reforming and modifying its process.

The review and study of Asian reform experiences provides an inspiring model for Egypt which has a distinctive experience in economic reform through its successive stages, from the beginning of financial reform in 2014 to the current stage of economic take-off which focuses on manufacturing, operation, and reform of the structure of foreign trade through the promotion of exports and the import substitution for domestic products, in addition to Egypt's successful experience in economic recovery from the effects of the covid-19 pandemic, as well as addressing its social effects. For the first time in many decades, Egypt has a worthwhile model for various countries of the world, including Asian countries with outstanding experiences over the past quarter of a century.

Moreover, this issue includes many studies and research on Asian political, security, economic and social issues, as well as a series of reports on current events in several countries and regions of the Asian continent, and reviews of international books on Asia, in addition to the English and Chinese sections.

We hope that this issue will benefit readers and those interested in Asian affairs. 